\title{
ANALISIS MANAJEMEN LABA TERHADAP NILAI PERUSAHAAN YANG TERDAFTAR DI BURSA EFEK INDONESIA
}

(Studi Khusus: Perusahaan Dagang Otomotif)

\author{
Poppy Indriani \\ Jaka Darmawan \\ Siti Nurhawa \\ (Universitas Bina Darma) \\ E-mail:poppy_ucat@yahoo.com \\ E-mail: jakadarmawan@yahoo.co.id
}

\begin{abstract}
The purpose of this study is to investigate and analyze the effect of earnings management on the value of the automobile trading company listed in Indonesia Stock Exchange (IDX). The number of auto sector companies listed in Indonesia Stock Exchange as many as 12 companies. The analysis technique used is simple linear regression.

Variable analysis showed a significant effect of earnings management on the value of companies listed on the Indonesia Stock Exchange (Special Study: Automotive Trade Company). It is expected that managers in conducting earnings management uses judgment in financial reporting and the preparation of financial statements of transactions to change on the economic performance of the organization or to influence the outcome in accordance with the contract depends on the accounting numbers that are reported to be in accordance with generally accepted accounting principles.
\end{abstract}

Keywords: Earnings Management, Automotive Trade Company, Firm Value.

\section{Latar Belakang}

Naik turunnya harga saham dipengaruhi oleh beberapa faktor. Salah satu dari faktorfaktor yang mempengaruhi naik turunnya harga saham di bursa yaitu laba dan dividen. Laba suatu perusahaan dan nilai perusahaan digambarkan oleh harga saham. Investor tertarik untuk berinvestasi di pasar modal karena adanya keterbukaan informasi. Salah satu informasi yang diperlukan di pasar modal adalah laporan keuangan perusahaan, yang didalamnya terdapat laba bersih perusahaan. Pada dasarnya laporan keuangan merupakan salah satu sumber informasi penting yang digunakan oleh investor dalam menilai kinerja perusahaan yang go publik. Informasi laba bersih yang diperoleh bisa dijadikan dasar untuk menilai seberapa besar nilai kembalian investasi yang dilakukan, atau untuk menilai seberapa besar earning yang diperoleh dari setiap saham yang dibeli investor. Jika laporan keuangan dapat menyajikan informasi yang relevan dengan model keputusan yang digunakan investor, maka investor akan menggunakan informasi tersebut untuk membuat keputusan buy, hold, atau sell 
saham. Akibatnya secara tidak langsung laba perusahaan dapat berpengaruh terhadap perubahan harga saham.

Jika perusahaan memiliki laba setiap tahunnya, maka perusahaan tersebut akan berpikir apakah dari laba yang di perolehnya tersebut akan di berikan semua atau sebagian atau seluruhnya di tahan untuk di investasikan kembali. Asimetri informasi antara manajer dan para pemegang saham memberikan keleluasaan bagi manajemen untuk bebas menentukan metode akuntansi dan estimasi yang digunakan dalam melaporkan laba perusahaan sehingga memberikan kesempatan bagi manajemen untuk melakukan manajemen laba. Pokok permasalahan yang akan di bahas dalam penelitian ini adalah bagaimana pengaruh manajemen laba terhadap nilai perusahaan yang terdaftar di Bursa Efek Indonesia (Studi Khusus: Perusahaan Dagang Otomotif)?

\section{Telaah Literatur dan Pengembangan Hipotesis}

Schiper (2009:76) mendefinisikan manajemen laba adalah suatu intervensi yang disengaja dilakukan untuk memperoleh beberapa keuntungan pribadi pihak tertentu. Healy dan Wahlen dalam Sulistyanto (2008:32) menyatakan manajemen laba terjadi ketika para manajer menggunakan pertimbangan dalam pelaporan keuangan dan penyusunan transaksi untuk merubah laporan keuangan tentang kinerja ekonomik organisasi atau untuk mempengaruhi hasil sesuai dengan kontrak yang tergantung pada angka-angka akuntansi yang dilaporkan.

Manajemen laba merupakan masalah keagenan yang seringkali dipicu oleh adanya pemisahan peran atau perbedaan kepentingan antara pemegang saham dengan manajemen perusahaan (Iqbal, 2007:41). Manajer melakukan manipulasi laba melalui manajemen laba agar laba nampak sebagaimana yang diharapkan.

Beberapa peneliti mendefinisikan manajemen laba dalam arti yang berbeda-beda. Dalam Sulistyanto (2008:32) terdapat beberapa definisi mengenai manajemen laba (earnings management) yaitu:

a. Schipper (1989)

Manajemen laba adalah campur tangan dalam proses penyusunan pelaporan keuangan dengan tujuan untuk mendapatkan keuntungan-keuntungan pribadi.

b. Fisher dan Rosenzweig (1995) 
Manajemen laba adalah tindakan-tindakan manajer untuk menaikkan (menurunkan) laba periode berjalan dari sebuah perusahaan yang dikelolanya tanpa menyebabkan kenaikan (penurunan) keuntungan ekonomi perusahaan jangka panjang.

c. Healy \& Wahlen (1999)

Manajemen laba terjadi apabila manajer menggunakan penilaian dalam pelaporan keuangan dan dalam struktur transaksi untuk mengubah laporan keuangan guna menyesatkan pemegang saham mengenai prestasi ekonomi perusahaan atau mempengaruhi akibat-akibat perjanjian yang mempunyai kaitan dengan angka-angka yang dilaporkan dalam laporan keuangan.

Manajemen laba adalah pemilihan kebijakan akuntansi tertentu oleh manajer untuk mencapai tujuan tertentu (Scott, 2007:45). Konsep manajemen laba ini sesuai dengan pendapat Davidson, Stickney, dan Weil dalam Sulistyanto (2008:61) yang menyatakan manajemen laba merupakan suatu proses pengambil langkah tertentu yang disengaja dalam batas prinsip akuntansi berterima umum untuk menghasilkan tingkat yang diinginkan dari laba yang dilaporkan. Definisi tersebut menunjukan manajemen laba sebagai aktivitas yang biasa dilakukan manajer dalam menyusun laporan keuangan. Upaya rekayasa manajerial ini dianggap lumrah dan bukan merupakan suatu pelanggaran atau kecurangan karena dilakukan dalam ruang lingkup prinsip akuntansi (Sulistyanto, 2008:35).Menurut Sugiri dalam Widyaningdyah (2008:92) membagi definisi manajemen laba menjadi dua, yaitu :

a. Definisi Sempit

Manajemen laba dalam hal ini hanya berkaitan dengan pemilihan metode akuntansi. Manajemen laba dalam artian sempit ini didefinisikan sebagai perilaku manajemen untuk "bermain" dengan komponen discretionary accrual dalam menentukan besarnya laba.

b. Definisi Luas

Manajemen laba merupakan tindakan manajer untuk meningkatkan (mengurangi) laba yang dilaporkan saat ini atas suatu unit dimana manajer bertanggung jawab, tanpa mengakibatkan peningkatan (penurunan) profitabilitas ekonomi jangka panjang unit tersebut.

Manajemen laba didorong oleh beberapa motivasi. Scott dalam Sukartha (2007:41) berpendapat bahwa ada beberapa faktor yang dapat memotivasi manajer melakukan manajemen laba, yaitu:

a. Rencana Bonus (Bonus Scheme) 
Para manajer yang bekerja pada perusahaan yang menerapkan rencana bonus akan berusaha mengatur laba yang dilaporkannya dengan tujuan dapat memaksimalkan jumlah bonus yang akan diterimanya.

b. Kontrak Utang Jangka Panjang (Debt Covenant)

Menyatakan bahwa semakin dekat suatu perusahaan kepada waktu pelanggaran perjanjian utang maka para manajer akan cenderung untuk memilih metoda akuntansi yang dapat memindahkan laba periode mendatang ke periode berjalan dengan harapan dapat mengurangi kemungkinan perusahaan mengalami pelanggaran kontrak utang.

c. Motivasi Politik (Political Motivations)

Menyatakan bahwa perusahaan-perusahaan dengan skala besar dan industri strategis cenderung untuk menurunkan laba terutama pada saat periode kemakmuran yang tinggi. Upaya ini dilakukan dengan harapan memperoleh kemudahan serta fasilitas dari pemerintah.

d. Motivasi Perpajakan (Taxation Motivations)

Menyatakan bahwa perpajakan merupakan salah satu motivasi mengapa perusahaan mengurangi laba yang dilaporkan. Tujuannya adalah dapat meminimalkan jumlah pajak yang harus dibayar.

e. Pergantian CEO (Chief Executive Officer)

Biasanya CEO yang mendekati masa pensiun atau masa kontraknya menjelang berakhir akan melakukan strategi memaksimalkan jumlah pelaporan laba guna meningkatkan jumlah bonus yang akan mereka terima. Hal yang sama akan dilakukan oleh manajer dengan kinerja yang buruk. Tujuannya adalah menghindarkan diri dari pemecatan sehingga mereka cenderung untuk menaikkan jumlah laba yang dilaporkan.

f. Penawaran Saham Perdana (Initital Public Offering)

Menyatakan bahwa pada awal perusahaan menjual sahamnya kepada publik, informasi keuangan yang dipublikasikan dalam prospektus merupakan sumber informasi yang sangat penting. Informasi ini penting karena dapat dimanfaatkan sebagai sinyal kepada investor potensial terkait dengan nilai perusahaan. Guna mempengaruhi keputusan yang dibuat oleh para investor maka manajer akan berusaha untuk menaikkan jumlah laba yang dilaporkan. 


\subsection{Pengertian Nilai Perusahaan}

Pengertian nilai perusahaan menurut Husnan dan Pudjiastuti (2007:7) menyatakan bahwa "Nilai perusahaan merupakan harga yang bersedia dibayar oleh calon pembeli apabila perusahaan tersebut dijual, semakin tinggi nilai perusahaan semakin besar kemakmuran yang akan diterima oleh pemilik perusahaan”. Sedangkan pengertian nilai perusahaan menurut Sartono (2008:487) menyatakan bahwa "Nilai perusahaan adalah nilai jual sebuah perusahaan sebagai suatu bisnis yang sedang beroperasi”. Memaksimumkan nilai perusahaan (atau harga saham) tidak identik dengan memaksimumkan laba per lembar saham (earning per share, EPS). Hal ini karena disebabkan oleh :

a. Memaksimumkan EPS mungkin memusatkan pada EPS saat ini.

b. Memaksimumkan EPS mengabaikan nilai waktu uang.

c. Tidak memperhatikan faktor risiko.

Perusahaan mungkin memperoleh EPS yang tinggi pada saat ini, tetapi apabila pertumbuhannya diharapkan rendah, maka dapat saja harga sahamnya lebih rendah apabila dibandingkan dengan perusahaan yang saat ini mempunyai EPS yang lebih kecil. Dengan demikian memaksimumkan nilai perusahaan juga tidak identik dengan memaksimumkan laba, apabila laba diartikan sebagai laba akuntansi (yang bisa dilihat dalam laporan rugi laba perusahaan). Sebaliknya memaksimumkan nilai perusahaan identik dengan memaksimumkan laba dalam pengertian ekonomi (economic profit). Hal ini disebabkan karena laba ekonomi diartikan sebagai jumlah kekayaan yang bisa dikonsumsikan tanpa membuat pemilik kekayaan tersebut menjadi lebih miskin.

Fama dalam Wahyudi dan Pawestri (2008:24) menyatakan nilai perusahaan akan tercermin dari harga pasar sahamnya. Dalam menentukan nilai perusahaan digunakan nilai pasar ekuitas atau equity market value (MEV) dan Tobin's Q. MEV adalah merupakan hasil perkalian antara jumlah saham yang beredar dengan harga saham penutupan akhir tahun. Metode Tobin's Q merupakan salah satu altematif yang digunakan dalam menentukan nilai perusahaan yang dikembangkan oleh Profesor James Tobin. Tujuan jangka panjang dari perusahaan adalah mengoptimalkan nilai perusahaan (Wahyudi dan Pawestri, 2008:52). Peningkatan nilai perusahaan dapat menggambarkan kesejahteraan pemilik perusahaan, sehingga pemilik perusahaan akan mendorong manajer agar bekerja lebih keras dengan menggunakan berbagai intensif untuk memaksimalkan nilai perusahaan.

Menurut Brigham (2007:92) nilai perusahaan diukur dengan Price Book Value (PBV). Rasio ini mengukur nilai yang diberikan pasar keuangan kepada manajemen dan organisasi 
perusahaan sebagai sebuah perusahaan yang terus tumbuh. Semakin tinggi harga saham semakin tinggi nilai perusahaan. Nilai perusahaan yang tinggi merupakan keinginan para pemilik perusahaan sebab nilai perusahaan yang tinggi menunjukkan kemakmuran pemegang saham yang tinggi. Menurut Gitman (2008:108) dalam meningkatkan nilai perusahaan ada beberapa faktor yang mempengaruhinya yaitu sebagai berikut:

a. Nilai likuiditas adalah jumlah uang yang dapat direalisasikan jika aktiva atau kelompok aktiva dijual sebagian ataupun seluruhnya pada saat perusahaan tidak berjalan baik.

b. Nilai berkesinambungan adalah jumlah aset yang dapat dijual perusahaan untuk melanjutkan operasi bisnis.

c. Nilai buku adalah nilai aktiva yang dicatat dalam akuntansi yaitu selisih antara nilai perolehan dengan biaya penyusutan.

d. Nilai pasar adalah harga pasar dimana aktiva diperdagangnkan pada pasar bebas.

e. Nilai intrinsik atau nilai wajar adalah nilai sekarang dari arus dana yang dibutuhkan di masa yang akan datang.

\section{Metodologi Penelitian}

\subsection{Objek Penelitian}

Penelitian dilakukan pada perusahaan sektor otomotif yang terdaftar di Bursa Efek Indonesia. Periode pengamatan penelitian dilakukan dari tahun 2008 - 2012. Pemilihan perusahaan otomotif sebagai objek penelitian dengan pertimbangan pada homogenitas dalam aktivitas. Adapun jumlah perusahaan sektor otomotif yang terdaftar di Bursa Efek Indonesia sebanyak 12 perusahaan.

\subsection{Teknik Analisis}

Teknik analisa yang digunakan dalam penelitian ini adalah analisis regresi linier sederhana menggunakan program SPSS. Kemudian hipotesis yang dilakukan menggunakan uji t yang menunjukkan seberapa jauh pengaruh satu variabel independen secara individual dalam menerangkan variabel dependen (Ghozali, 2007). Uji t dilakukan dengan melihat nilai probabilitas signifikansi t variabel bebas. Jika nilai probabilitas signifikansi t lebih kecil dari 0,05 maka dapat dikatakan bahwa ada pengaruh yang kuat antara variabel independen dengan variabel dependen. 


\section{Hasil Penelitian dan Pembahasan}

\subsection{Hasil Penelitian}

Pengujian hipotesis dilakukan dengan cara membandingkan antara tingkat signifikansi (sig) dengan tingkat kesalahan $(\alpha)=5 \%$. Apabila tingkat signifikansi yang diperoleh lebih kecil dari 0,05 variabel independen tersebut berpengaruh terhadap variabel dependennya. Pada tabel 1 terlihat bahwa tingkat signifikansi untuk variabel manajemen laba sebesar 0,000 lebih kecil dari $\alpha=0,05$ maka dapat dinyatakan bahwa $\mathrm{H} 0$ ditolak dan $\mathrm{H} 1$ diterima yang berarti terdapat pengaruh yang signifikan antara variabel manajemen laba dengan nilai perusahaan.

Pengaruh manajemen laba terhadap nilai perusahaan secara statistik dapat pula dilihat dengan membandingkan antara nilai $t_{\text {hitung }}$ dan $t_{\text {tabel }}$, dimana jika nilai $t_{\text {hitung }}>t_{\text {tabel }}$ berarti terdapat pengaruh. Namun jika $t_{\text {hitung }}<t_{\text {tabel }}$ hal tersebut berarti tidak terdapat pengaruh. Berdasarkan hasil perhitungan sebagaimana yang dapat dilihat pada tabel 1 diperoleh nilai $\mathrm{t}_{\text {hitung }}$ hitung sebesar 4,716 kemudian dibandingkan dengan $\mathrm{t}_{\text {tabel }}$ sebesar 2,012 (signifikansi $=$ $5 \%: 2=0,025$ pengujian dua sisi dan $\mathrm{df}=\mathrm{n}-1=48-1=47$ ). Sehingga di dapat $\mathrm{t}_{\text {hitung }} 4,716$ $>t_{\text {tabel }} 2,012$, oleh karena itu dapat dikatakan bahwa H0 ditolak dan H1 diterima yang berarti terdapat pengaruh yang signifikan antara variabel manajemen laba dengan nilai perusahaan. Selanjutnya untuk melihat seberapa besar pengaruh variabel manajemen laba dengan nilai perusahaan dapat dilihat pada tabel model summary. Berdasarkan pengolahan data diperoleh hasil sebagai berikut:

\section{Tabel 1}

Model Summary

\begin{tabular}{|l|l|l|l|l|l|}
\hline Model & $R$ & R Square & $\begin{array}{l}\text { Adjusted } \\
\text { Square }\end{array}$ & $\begin{array}{l}\text { Std. Error of } \\
\text { the Estimate }\end{array}$ & $\begin{array}{l}\text { Wurbin- } \\
\text { Watson }\end{array}$ \\
\hline 1 & $.571^{\mathrm{a}}$ & .326 & .311 & 1.11105 & .122 \\
\hline
\end{tabular}

a. Predictors: (Constant), Manajemen Laba

b. Dependent Variable: Price Book Value

Berdasarkan tabel $1 \mathrm{di}$ atas diketahui nilai $\mathrm{R}$ square sebesar 0,326 yang berarti bahwa variabel manajemen laba mempengaruhi variabel nilai perusahaan sebesar 32,6\% sedangkan sisanya sebesar $67,4 \%$ dipengaruhi oleh faktor lain diluar penelitian ini seperti corporate governance, struktur modal, nama baik perusahaan dan lain-lain. 


\subsection{Pembahasan}

Variabel manajemen laba bengaruh signifikan terhadap nilai perusahaan, dimana variabel manajemen laba mempengaruhi variabel nilai perusahaan sebesar 32,6\% sedangkan sisanya sebesar $67,4 \%$ dipengaruhi oleh faktor lain diluar penelitian. Variabel manajemen laba mempunyai sebaran yang besar karena standar deviasi lebih besar daripada nilai rata-rata (mean), sehingga simpangan data pada variabel manajemen laba ini dapat dikatakan tidak baik. Pihak manajer dalam proses mengambil langkah tertentu dalam melakukan manajemen laba dalam batas prinsip akuntansi berterima umum harus menghasilkan tingkat yang diinginkan dari laba yang dilaporkan.

Para manajer diharapkan dalam melaksanakan manajemen laba yang menggunakan pertimbangan dalam pelaporan keuangan dan penyusunan transaksi untuk merubah laporan keuangan tentang kinerja ekonomi organisasi atau untuk mempengaruhi hasil sesuai dengan kontrak yang tergantung pada angka-angka akuntansi yang dilaporkan harus sesuai dengan prinsip akuntansi yang diterima umum. Manajemen laba dipicu oleh adanya pemisahan peran atau perbedaan kepentingan antara pemegang saham dengan manajemen perusahaan, oleh sebab itu manajer melakukan manipulasi laba melalui manajemen laba agar laba nampak sebagaimana yang diharapkan.

Laba adalah naiknya nilai equity dari transaksi yang sifatnya insidentil dan bukan kegiatan utama entity dari transaksi atau kejadian lainnya yang mempengaruhi entity selama satu periode tertentu kecuali yang berasal dari hasil atau investasi dari pemilik. Laba merupakan indikator yang sering digunakan untuk mengukur tingkat keberhasilan kinerja operasional perusahaan. Berdasarkan informasi laba, para pengguna laporan keuangan baik internal perusahaan maupun eksternal perusahaan akan menggunakan informasi tersebut sebagai dasar dalam pengambilan keputusan yang menyangkut perusahaan diantaranya:

a. Indikator efisiensi penggunaan dana yang tertanam dalam perusahaan yang diwujudkan dalam tingkat kembalian.

b. Pengukur prestasi manajemen.

c. Dasar penentuan besarnya pengenaan pajak.

d. Alat pengendalian alokasi sumber daya ekonomi suatu negara.

e. Dasar kompensasi dan pembagian bonus.

f. Alat motivasi manajemen dalam pengendalian perusahaan.

g. Dasar untuk kenaikan kemakmuran.

h. Dasar pembagian dividen. 
Tujuan jangka panjang dari perusahaan adalah mengoptimalkan nilai perusahaan dengan memperoleh laba yang sebesar-besarnya. Peningkatan nilai perusahaan dapat menggambarkan kesejahteraan pemilik perusahaan, sehingga pemilik perusahaan akan mendorong manajer agar bekerja lebih keras dengan menggunakan berbagai intensif untuk memaksimalkan nilai perusahaan.

Pada penelitian ini variabel nilai perusahaan (Price Book Value) mempunyai sebaran kecil karena standar deviasi lebih kecil daripada nilai rata-rata (mean), sehingga simpangan data pada variabel Price Book Value ini dapat dikatakan baik. Oleh sebab itu para manajer perusahaan otomotif harus tetap mempertahankan dan lebih meningkatkan lagi nilai perusahaan dimasa yang akan datang. Hal ini perlu peran dari pemilik perusahaan untuk mendorong manajer agar bekerja lebih keras dengan menggunakan berbagai intensif (bonus, fasilitas kerja, fasilitas perumahan dan kendaraan, serta kenaikan gaji) untuk memaksimalkan nilai perusahaan.

\section{Simpulan dan Saran}

\subsection{Simpulan}

Berdasarkan hasil penelitian dan pembahasan yang sudah dilakukan, maka dapat disimpulkan bahwa:

1. Variabel manajemen laba berpengaruh signifikan terhadap nilai perusahaan yang terdaftar di Bursa Efek Indonesia (Studi Khusus: Perusahaan Dagang Otomotif).

2. Variabel manajemen laba mempengaruhi variabel nilai perusahaan dengan kategori lemah yaitu sebesar 32,6\% sedangkan sisanya sebesar $67,4 \%$ dipengaruhi oleh faktor lain diluar penelitian ini seperti corporate governance, struktur modal, nama baik perusahaan dan lain-lain.

3. Nilai Price Book Value (Y) rata-ratanya adalah sebesar 1,7177 dengan standar deviasi (std deviation) sebesar 1,33880 yang berarti simpangan data pada variabel Price Book Value ini dikatakan baik.

4. Nilai manajemen laba (X) rata-ratanya adalah sebesar -0.030895242 dengan standar deviasi (std deviation) sebesar 0.3748513798 yang berarti variabel manajemen laba mempunyai sebaran yang besar karena standar deviasi lebih besar daripada nilai ratarata (mean), sehingga simpangan data pada variabel manajemen laba ini dikatakan tidak baik. 


\subsection{Saran}

Berdasarkan hasil penelitian yang diperoleh, penulis mengajukan beberapa saran yang diharapkan dapat bermanfaat bagi perkembangan perusahaan dimasa yang akan datang.

1. Para manajer diharapkan dalam melaksanakan manajemen laba yang menggunakan pertimbangan dalam pelaporan keuangan dan penyusunan transaksi untuk merubah laporan keuangan tentang kinerja ekonomi organisasi atau untuk mempengaruhi hasil sesuai dengan kontrak yang tergantung pada angka-angka akuntansi yang dilaporkan harus sesuai dengan prinsip akuntansi yang diterima umum. Manajemen laba dipicu oleh adanya pemisahan peran atau perbedaan kepentingan antara pemegang saham dengan manajemen perusahaan, oleh sebab itu manajer melakukan manipulasi laba melalui manajemen laba agar laba nampak sebagaimana yang diharapkan.

2. Manajemen laba mempengaruhi nilai perusahaan sangat lemah, oleh sebab itu untuk meningkatkan nilai perusahaan yang lebih optimal dimasa yang akan datang, diharapkan perusahaan melakukan manajemen laba dengan memperhatikan faktor faktor yang dapat memotivasi manajer melakukan manajemen laba seperti:

a. Rencana Bonus

Para manajer yang bekerja pada perusahaan yang menerapkan rencana bonus akan berusaha mengatur laba yang dilaporkannya dengan tujuan dapat memaksimalkan jumlah bonus yang akan diterimanya.

b. Kontrak Utang Jangka Panjang

Menyatakan bahwa semakin dekat suatu perusahaan kepada waktu pelanggaran perjanjian utang maka para manajer akan cenderung untuk memilih metoda akuntansi yang dapat memindahkan laba periode mendatang ke periode berjalan dengan harapan dapat mengurangi kemungkinan perusahaan mengalami pelanggaran kontrak utang.

c. Motivasi Politik

Menyatakan bahwa perusahaan-perusahaan dengan skala besar dan industri strategis cenderung untuk menurunkan laba terutama pada saat periode kemakmuran yang tinggi. Upaya ini dilakukan dengan harapan memperoleh kemudahan serta fasilitas dari pemerintah. 
d. Motivasi Perpajakan

Menyatakan bahwa perpajakan merupakan salah satu motivasi mengapa perusahaan mengurangi laba yang dilaporkan. Tujuannya adalah dapat meminimalkan jumlah pajak yang harus dibayar.

e. Pergantian CEO

Biasanya CEO yang mendekati masa pensiun atau masa kontraknya menjelang berakhir akan melakukan strategi memaksimalkan jumlah pelaporan laba guna meningkatkan jumlah bonus yang akan mereka terima. Hal yang sama akan dilakukan oleh manajer dengan kinerja yang buruk. Tujuannya adalah menghindarkan diri dari pemecatan sehingga mereka cenderung untuk menaikkan jumlah laba yang dilaporkan.

f. Penawaran Saham Perdana

Menyatakan bahwa pada awal perusahaan menjual sahamnya kepada publik, informasi keuangan yang dipublikasikan dalam prospektus merupakan sumber informasi yang sangat penting. Informasi ini penting karena dapat dimanfaatkan sebagai sinyal kepada investor potensial terkait dengan nilai perusahaan. Guna mempengaruhi keputusan yang dibuat oleh para investor maka manajer akan berusaha untuk menaikkan jumlah laba yang dilaporkan.

3. Nilai perusahaan otomotif sudah dianggap baik oleh sebab itu para manajer perusahaan otomotif harus tetap mempertahankan dan lebih meningkatkan lagi nilai perusahaan dimasa yang akan datang. Hal ini perlu peran dari pemilik perusahaan untuk mendorong manajer agar bekerja lebih keras dengan menggunakan berbagai intensif (bonus, fasilitas kerja, fasilitas perumahan dan kendaraan, serta kenaikan gaji) untuk memaksimalkan nilai perusahaan.

4. Nilai variabel manajemen laba perusahaan otomotif belum dianggap baik oleh sebab itu manajer dalam proses mengambil langkah tertentu dalam melakukan manajemen laba dalam batas prinsip akuntansi berterima umum harus menghasilkan tingkat yang diinginkan dari laba yang dilaporkan. Upaya rekayasa manajerial ini dianggap lumrah dan bukan merupakan suatu pelanggaran atau kecurangan karena dilakukan dalam ruang lingkup prinsip akuntansi. 


\section{DAFTAR PUSTAKA}

Baridwan. 2007. Intermidiate Accounting. Salemba Empat: Jakarta

Darmadji T. dan Hendy M. Fakhfuddin. 2006. Pasar Modal Di Indonesia. Penerbit Salemba Empat: Jakarta.

Ferdawati. 2008. Pengaruh Manajemen Laba Real Terhadap Nilai Perusahaan. Politeknik Negeri Padang.

Ghufron . 2006. Pengaruh Informasi Laba, Dan Arus Kas Terhadap Abnormal Return Saham Pada Perusahaan Manufaktur Yang Terdaftar Di BEJ. PENELITIAN. Universitas Brawijaya Malang.

Gujarati, Damodar. 1999. Essentials Of Econometric, Second Edition. McGraw-Hill Companies: United State.

Gunawan dan Bandi. 2000. Teori Portofolio dan analisis Investasi. Edisi ketiga. BPFE. Yogyakarta.

Harahap, Sofyan safri. 2008. Analisis Krisis Atas Laporan Keuangan. Cetakan keempat. PT Raja Grafindo Persada . Jakarta.

Healy dan Wahlen. 2008. Accounting Intermediate standard. Jakarta : Salemba Empat.

Herman, Darwis. 2010. Manajemen Laba Terhadap Nilai Perusahaan dengan Corporate Governance Sebagai Pemoderasi. Universitas Pembangunan Jakarta.

Herawaty. 2008. Pengaruh Earning Management Terhadap Nilai Perusahaan.

Husnan, Suad. 2005. Dasar-Dasar Teori Portofolio dan Analisis Sekuritas. Edisi Keempat. Penerbit UUP AMP YKPN: Yogyakarta.

I Gusti Ayu Putu Shita P. 2011. Analisis Faktor - Faktor yang Berpengaruh Terhadap Manajemen Laba (Studi pada Perusahaan Sektor Perbankan yang Terdaftar di BEI Tahun 2006 - 2008). Universitas Diponegoro Semarang.

Jogianto, 2000. Teori Portovolio dan Analisis Investasi. Edisi kedua Yogyakarta : BPFE.

Komaruddin, Ahmad. 2004. Dasar-Dasar Manajemen Investasi dan Portofolio. Penerbit PT. Reneka Cipta: Jakarta.

Niswonger. C.Rollin., et al. 2000. Prinsip-Prinsip Akuntansi. Penerbit Erlangga: Jakarta.

Okta Rezika Praditia. 2010. Analisis Pengaruh Mekanisme Corporate Governance Terhadap Manajemen Laba dan Nilai Perusahaan Pada Perusahaan Manufaktur yang Terdaftar di BEI Pada Tahun 2005 - 2008. 
Santoso. 2007. SPSS Statistik Parametrik. Penerbit PT Elex Media Komputindo: Jakarta.

Schiper. 2009. Accounting Intermediate. Jilid I, Edisi Kesepuluh, Jakarta : Penerbit Erlangga.

Scott. 2007. Pasar Modal (Teori, Masalah, dan Kebijakan dalam Praktek). Penerbit Alfabeta: Bandung.

Singgih, Santoso. 2000. Buku Latihan SPSS Statistik Parametrik, Penerbit Elex Media Komputindo, Jakarta.

Soemarso. 2007. Akuntansi Suatu Pengantar. Rosda Karya: Bandung

Sukartha. 2007. Pengantar Pengetahuan Pasar Modal. Penerbit UUP AMP YKPN: Yogyakarta.

Sulistyanto. 2008. Pengaruh Informasi Laba, Arus Kas Dan Komponen Arus Kas Terhadap Harga Saham. PENELITIAN. Universitas Brawijaya Malang.

Widyaningdyah. 2008. Akuntansi Keuangan dan Manajemen. Edisi Pertama. Yogyakarta. BPEF 